\title{
Anastazja Mołodecka
}

Centrum Badań Młodzieży

(iD) https://orcid.org/0000-0002-3973-8972

$\triangle$ anastazjamolodecka@gmail.com

\section{PROBLEM ZABURZEŃ ZDROWIA PSYCHICZNEGO MŁODZIEŻY W DOBIE PANDEMII Z PERSPEKTYWY PSYCHOLOGII}

\section{THE PROBLEM OF MENTAL HEALTH DISORDERS IN ADOLESCENTS IN THE PANDEMIC TIME FROM THE PERSPECTIVE OF PSYCHOLOGY}

D0I: 10.24917/ycee.2020.11.88-92

Abstrakt:

W artykule przedstawiono sytuację emocjonalną młodzieży w czasie pandemii COVID-19. Metaanaliza bazująca na badaniach zdrowia psychicznego młodzieży w Polsce oraz innych krajach wskazuje, że w obliczu izolacji spowodowanej pandemią reprezentanci tej grupy wiekowej są szczególnie narażeni na różnego rodzaju zaburzenia zdrowia psychicznego. Celem artykułu jest udzielenie odpowiedzi na pytanie, co predysponuje młodzież do tak negatywnych reakcji. Przywołane zostają teorie psychologiczne A. Maslowa oraz E. H. Eriksona ukazujące specyficzne potrzeby rozwojowe młodzieży. Na gruncie tych teorii można sformułować wniosek, że przyczyną obserwowanych obecnie problemów psychicznych młodzieży jest deprywacja ich potrzeb rozwojowych.

Słowa kluczowe: $\quad$ Abraham Maslow, Erik H. Erikson, izolacja, młodzież, pandemia COVID-19

Abstract: $\quad$ The article presents the mental problems of young people during the COVID-19 pandemic. A meta-analyses based on research into the mental health of adolescents in Poland and other countries show that in the face of pandemic isolation it has got huge influence on people. Especially in between youngsters who are particularly exposed to various types of mental health disorders. The intent of the article is to answer the question what predisposes young people to such negative feelings. Most of all, the psychological theories of A. Maslow and E. H. Erikson are specified showing the unusual development of needs of young people. Due to these theories, it can be concluded that the cause of the recently observed mental problems of adolescents is the deprivation of their developmental necessities.

Keywords:

\section{Stres a zdrowie}

C zwartego marca 2020 roku wykryto w Polsce pierwszy przypadek COVID-ı9, a I2 dni później wprowadzono na terenie całego kraju lockdown. Podobne sytuacje miały miejsce w innych państwach naszego kręgu kulturowego. Społeczeństwa zachodnie zostały skonfrontowane z sytuacją dotychczas nieznaną, zmuszającą do zmiany zachowań i przyzwyczajeń (zdalny tryb 
pracy i edukacji, stosowanie środków ochrony osobistej), ograniczającą swobodę decyzji (ograniczona możliwość przemieszczania się; okresowo zamykane centra handlowe, hotele, restauracje, obiekty sportowe i kulturalne. W niektórych państwach wprowadzano godzinę policyjną czy stan wyjątkowy). Nowe, nieznane wcześniej warunki wywołały niepokój. Jednostki, ale także zbiorowości, utraciły poczucie bezpieczeństwa. Wzrosły wskaźniki zachorowań oraz śmiertelności. Pogorszyła się sytuacja gospodarstw domowych i w wielu krajach spadła wartość PKB.

Początkowa nadzieja, że mamy do czynienia z sytuacją przejściową, w miarę przedłużania się stanu pandemii przerodziła się $\mathrm{w}$ permanentne poczucie zagrożenia i niepewności. W wyniku trwającej już ponad rok pandemii doszło do tak znaczącej kumulacji niekorzystnych zmian, że przekroczone zostały społeczne możliwości adaptacyjne.

Szereg badań psychologicznych wskazuje na to, że przeciągająca się sytuacja stresowa jest bardzo niekorzystna dla zdrowia i prowadzi do długofalowych negatywnych konsekwencji. Thomas Holmes i Richard Rahe (1967), wykorzystując Kwestionariusz zmian życiowych (Recent Life Changes Questionnaire, RLCQ), wskazali na zależność pomiędzy znaczącymi wydarzeniami w życiu człowieka, wymagającymi uruchomienia mechanizmów adaptacji do nowej sytuacji, a późniejszą zapadalnością na choroby ${ }^{1}$. Podobne wyniki zaprezentowali Adam Sobolewski, Jan Strelau i Bogdan Zawadzki (1999), którzy wykazali związek ilości i jakości krytycznych zdarzeń życiowych w określonym okresie życia

Chodzi tu nie tylko o niekorzystne wydarzenia w życiu człowieka (rozwód, choroba itp.), ale i korzystne (awans, narodziny dziecka, małżeństwo itp.). Każdemu z takich wydarzeń została przyporządkowana określona liczba punktów mierzących koszt emocjonalny z nim związany (np. rozwód - 80,08, awans - 31,18). Przekroczenie przez osobę I50 punktów w okresie dwóch lat oznacza przekroczenie możliwości organizmu do adaptacji i naraża tę osobę na poważne problemy zdrowotne. z późniejszą podatnością na choroby serca czy zaburzenia psychiczne.

Teoria granic adaptacyjnych oraz stresu adaptacyjnego stanowi punkt wyjścia prowadzonych analiz. W perspektywie tej teorii ukazana zostanie specyfika sytuacji młodzieży w czasie pandemii. W wypadku tej grupy wiekowej mamy bowiem do czynienia nie tylko z przeciążeniem adaptacyjnym, ale również z deprywacją potrzeb rozwojowych.

\section{Wpływ pandemii na zdrowie psychiczne młodzieży}

Badania przeprowadzone podczas pandemii wśród studentów Uniwersytetu Pedagogicznego w Krakowie wykazały, że „64\% respondentów jest zmęczona, $62 \%$ objawia wyczerpanie psychiczne, $60 \%$ miewa wahania nastrojów, $59 \%$ ma mniejszą motywację do nauki, $56 \%$ nie jest wypoczęta nawet po weekendowej przerwie" (Długosz, Foryś, 2020, s. 23). Z kolei autorzy raportu na temat kondycji psychicznej polskiego społeczeństwa w 2020 roku przygotowanego przez Centrum Badań Opinii Społecznej wskazują, że choć stany obniżenia nastroju i zaburzenia emocjonalne mają wymiar powszechny, to w wśród młodych osób występują one ze szczególnym nasileniem:

Samopoczucie Polaków w 2020 roku uległo wyraźnemu pogorszeniu w stosunku do roku 2019, co można wiązać z wybuchem pandemii COVID-19. Zmniejszyły się odsetki deklaracji wszystkich wymienianych w naszych pytaniach emocji pozytywnych, a zwiększyła ilość deklaracji wszystkich emocji negatywnych. Spadła zwłaszcza liczba osób odczuwających regularnie pewność, że wszystko układa się dobrze. [. . .] Szczególną uwagę zwraca najmłodsza grupa badanych, w wieku 18-24 lata, w której częstość występowania stanów depresyjnych, poczucia bezradności, a także zniechęcenia i znużenia osiągnęła najwyższe poziomy na przestrzeni ostatnich dwóch dekad (CBOS, 2021).

Problem obserwowany wśród młodzieży polskiej ma wymiar globalny. Również w innych 
krajach młodzi ludzie nie radzą sobie z obowiązkiem izolacji i ograniczeniem wolności ${ }^{2}$. Raport UNICEF (2020) na temat kondycji młodych osób w czasie pandemii wskazuje na szereg negatywnych konsekwencji: $27 \%$ osób odczuwa niepokój, 15\% - depresję w czasie ostatnich siedmiu dni; $46 \%$ osób czuje się mniej zmotywowanych do podejmowania aktywności, które zazwyczaj lubili, a 35\% osób czuje się mniej zmotywowanych do wykonywania regularnych obowiązków ${ }^{3}$.

Powszechne wśród młodzieży jest łamanie restrykcji epidemicznych: nienoszenie maseczek, nierespektowanie zasad dystansu społecznego. Organizowane są nielegalne spotkania, imprezy klubowe. W Holandii po zaostrzeniu restrykcji spowodowanych trzecią falą COVID-ı doszło do serii brutalnych protestów młodych ludzi, którzy nie chcieli się zgodzić na wprowadzenie godziny policyjnej. Strajkujące osoby zachowywały się wyjątkowo agresywnie - wybijały szyby w sklepach, rzucały przedmiotami w policję.

W perspektywie powyższych danych należy sformułować pytanie, dlaczego spośród różnych grup wiekowych to młodzież ma największe problemy z dostosowaniem się do nowych warunków. Dlaczego psychologiczne następstwa obecnego kryzysu najbardziej dotykają właśnie ludzi młodych?

\section{Potrzeby rozwojowe młodzieży}

Psychologia dostarcza pewnych podpowiedzi w naszych poszukiwaniach. Wskazuje na szczególne aspekty życia młodych ludzi, które w czasie

Powstał specjalny program „The Depressed Project” (Thombs, B. D., Bonardi, O., et al., 2020), w ramach którego zbierane są wyniki prowadzonych w różnych krajach badań na temat wpływu pandemii COVID-I9 na zdrowie psychiczne. Wiele spośród nich dotyczy młodych ludzi. Badaniom towarzyszą komentarze ekspertów.

3 Odnośny raport przygotowany został na podstawie 8444 ankiet wypełnionych przez osoby między I3 a 29 rokiem życia z 9 krajów Ameryki Łacińskiej i Karaibów. pandemii narażają tę grupę na większe ryzyko zaburzeń psychicznych. Różne szkoły psychologiczne opisują ten proces za pomocą właściwych sobie kategorii, jednak łączy je ogólna charakterystyka potrzeb rozwojowych młodzieży. Najważniejszą w perspektywie rozwoju psychospołecznego cechą młodości jest emancypacja ze środowiska rodzinnego i poszukiwanie własnego miejsca w społeczeństwie. Pisali o tym na przykład Abraham Maslow (Maslow, 1990), psycholog wywodzący się z nurtu humanistycznego, oraz Erik H. Erikson (Erikson, 2004), reprezentujący podejście psychoanalityczne.

A. Maslow opracował uniwersalną w zamyśle hierarchię potrzeb ludzkich. Porządkuje ona zdaniem autora wszystkie potrzeby człowieka od najbardziej podstawowych (fizjologicznych), poprzez społeczne, do potrzeb wyższego szczebla (związanych z samorealizacją). Pandemia COVID-ı9 „zachwiała” całą piramidą Maslowa. Najpierw zagroziła naszemu bezpieczeństwu egzystencjalnemu i materialnemu. Następnie radykalnie ograniczyła kontakty międzyludzkie, utrudniając zaspokojenie potrzeb społecznych. W warunkach zamknięcia ośrodków kultury i sportu również potrzeby związane z samorealizacją były często niemożliwe do spełnienia.

Zwróćmy uwagę, że w kontekście młodzieży szczególne znaczenie ma drugie, społeczne, piętro piramidy Maslowa. Kontakty rówieśnicze mają kluczowe znaczenie w procesie dojrzewania młodych ludzi. Budują ich tożsamość, zaspokajają potrzebę przynależności, akceptacji i uznania. Potrzeb społecznych młodzieży nie jest w stanie zaspokoić środowisko rodzinne - jedyne dostępne w warunkach nauczania zdalnego. To stawia ja w sytuacji bardzo niekomfortowej, a niekiedy wręcz traumatycznej.

Kolejną teorią psychologiczną wartą przywołania w omawianym kontekście jest teoria rozwoju psychospołecznego E. H. Eriksona. Teoria ta opisuje rozwój człowieka od narodzin do śmierci jako przechodzenie przez kolejne stadia rozwojowe. Na każdym etapie człowiek przeżywa 
kryzys rozwojowy, po jego rozwiązaniu jednostka zdobywa zaś cenną umiejętność - cnotę. W odniesieniu do okresu młodości Erikson wymienia trzy etapy rozwoju: dojrzewanie (8-I2 lat), okres młodzieńczy (13-22 lata) oraz okres wczesnej dorosłości (23-34 lata). W okresie dojrzewania dziecko jest na etapie konfliktu rozwojowego: pracowitość versus poczucie niższości. $\mathrm{Na}$ tym etapie uczy się zaangażowania w pracę, cierpliwości, systematyczności, zaś niepowodzenie w tej fazie może skutkować zaniżeniem samooceny lub niezdolnością doprowadzania spraw do końca. W warunkach edukacji zdalnej nauka powyższych umiejętności w dużej mierze spada na rodziców, którzy, zajęci swoimi obowiązkami, nie są w stanie im podołać.

W okresie okres młodzieńczym rozgrywa się natomiast konflikt rozwojowy: poczucie tożsamości versus pomieszanie ról. Młody człowiek może zyskać poczucie integralności wewnętrznej albo odczucie obcości w rolach społecznych. Czeka go na tym etapie wybór ścieżki zawodowej oraz partnera seksualnego. Próbując różnych rzeczy i podejmując samodzielne decyzje, ma okazję sprawdzić siebie oraz otoczenie. W sytuacji ograniczenia kontaktów społecznych zbudowanie niezależnej tożsamości staje się o wiele trudniejsze, podobnie jak nawiązanie zadowalających relacji rówieśniczych. Przyjaźń czy wybór partnera seksualnego w warunkach ograniczeń pandemicznych stają się praktycznie niemożliwe.

W stadium rozwoju przypadającym na okres wczesnej dorosłości ma według Eriksona miejsce konflikt między intymnością a izolacją. W tym czasie uczymy się wzajemności, bycia blisko drugiego człowieka. Wyrazem klęski poniesionej na tym etapie rozwojowym jest unikanie intymności, powierzchowne związki. W czasach obostrzeń epidemicznych nawiązanie intymnej relacji z drugim człowiekiem, a więc rozwiązanie wyżej wspomnianego konfliktu rozwojowego, staje się utrudnione.

Widzimy zatem, że w odniesieniu do młodych ludzi ograniczenia związane z pandemią uniemożliwiają rozwiązanie naturalnych konfliktów rozwojowych i utrudniają proces dojrzewania psychospołecznego. Na kolejnych etapach rozwoju mamy do czynienia z ludźmi już psychicznie ukształtowanymi, dla których ważniejsza staje się kariera, wychowanie dzieci i pielęgnowanie życia, na które zapracowali się wcześniej. Potrzebom rozwojowym tych osób ograniczenia epidemiczne zagrażają w mniejszym stopniu.

\section{4. Środki zaradcze}

Młodzi ludzie w czasach pandemii - zamknięci w domach, zmuszeni do ponadwymiarowych kontaktów $\mathrm{z}$ rodziną, pozbawieni bezpośrednich relacji z rówieśnikami - mogą czuć się bardzo samotni i niezrozumiani. Oprócz kontaktów społecznych utrudniona jest również realizacja różnego rodzaju hobby. Deprywacja podstawowych potrzeb młodzieży może prowadzić do frustracji, zachowań agresywnych czy zaburzeń psychicznych. Należy przeciwdziałać tym niekorzystnym i niebezpiecznym zjawiskom.

Poszukując metod pomocy młodzieży w jej trudnym położeniu w czasie pandemii, warto skorzystać ze znanych technik relaksacyjnych (medytacja, joga, świadomy oddech, mindfulness), pomocy z zakresu psychologii pozytywnej (np. prowadzenie dzienniczka wdzięczności, zadbanie o wykorzystywanie swoich mocnych stron, skupienie się na angażującej aktywności, w której tracimy poczucie czasu - stan flow albo zaangażowanie się w coś „większego od nas samych”, np. w pomoc potrzebującym) czy aktywności fizycznej możliwej w warunkach istniejących ograniczeń. Można też skorzystać z udogodnień technologicznych i pielęgnować kontakty społeczne online, nawet jeśli nie są one w pełni zadowalające i nie zastępują czasu spędzanego w fizycznej bliskości. Oczywiście, przy dłużej trwającym obniżeniu nastroju, depresji, stanach lękowych należy skorzystać z profesjonalnej pomocy psychoterapeutycznej. 


\section{Podsumowanie}

Metaanaliza badań kondycji psychicznej młodzieży w czasie pandemii COVID-ı9 wskazuje na wyjątkową wrażliwość emocjonalną reprezentantów tej grupy wiekowej oraz na pogarszanie się ich stanu zdrowia psychicznego w warunkach ograniczeń epidemicznych. Obniżeniu ulega szereg wskaźników dobrostanu psychicznego młodzieży. W poszukiwaniu odpowiedzi na pytanie, dlaczego młodzi ludzie w czasie pandemii są o wiele bardziej niż inne grupy wiekowe narażeni na rozwój chorób psychicznych, przywołane zostały koncepcje psychologiczne A. Maslowa oraz E. H. Eriksona. Wymienieni autorzy podkreślają specyficzne potrzeby rozwojowe młodzieży. Choć reprezentują odmienne szkoły psychologiczne, obaj zgadzają się co do tego, że w okresie młodości ujawniają się następujące potrzeby: kontaktu z rówieśnikami, przynależności do grupy rówieśniczej, budowania własnej, niezależnej od rodziny tożsamości oraz eksperymentowania. Ograniczenia pandemiczne sprawily, że zaspokojenie odnośnych potrzeb rozwojowych stało się niemożliwe. Zablokowana została ekspresja naturalnych instynktów młodych osób. Deprywacja ich potrzeb rozwojowych w połączeniu $\mathrm{z}$ naturalną $\mathrm{w}$ okresie młodzieńczym potrzebą buntu i niepewnością o przyszłość spowodowała pogorszenie stanu psychicznego oraz doprowadziła do aktów agresji. Zastanawiając się nad formą pomocy młodzieży w tak trudnym dla niej okresie, warto sięgnąć do sprawdzonych naukowo sposobów poprawy dobrostanu psychicznego oferowanych w ramach psychologii pozytywnej.

\section{Bibliografia}

Czapiński, J. (red.). (2004). Nowe tendencje w psychologii. Psychologia pozytywna. Nauka o szczęściu, zdrowiu, sile i cnotach człowieka. Warszawa: Wydawnictwo Naukowe PWN.

Długosz P., Foryś G. (2020). Zdalne nauczanie na Uniwersytecie Pedagogicznym im. Komisji Narodowej w Krakowie z perspektywy studentów i wykładowców. Kraków: Wydawnictwo Naukowe Uniwersytetu Pedagogicznego.

Erikson, E. H. (1950). Childhood and society. New York: Norton. Erikson, E. H. (1968). Identity, youth and crisis. New York: Norton. Erikson, E. H. (1970). Jugend und Krise. Stuttgart: Klett.

Erikson, E. H. (2000). Dzieciństwo i społeczeństwo. Warszawa: Rebis.

Erikson, E. H. (2004). Tożsamość a cykl życia. Poznań: Zysk i S-ka.

Erikson, E. H., Erikson J. M. (2011). Dopełniony cykl życia. Gliwice: Helion SA.

Holmes, T. H., Rahe, R. H. (1967). The Social Readjustment Scale. Journal of Psychosomatic Research, 11, 213-218.

Kaczmarek, Ł. D. (2016). Pozytywne interwencje psychologiczne. Dobrostan a zachowania intencjonalne. Poznań: Zysk i S-ka.

Kaczmarek, Ł. D., Sęk, H. (red.). (2004). W stronę psychologii pozytywnej. Poznań: Bogucki Wyd. Naukowe.

Scovil, J. (2021). Samopoczucie Polaków w roku 2020 (komunikat z badań (BOS). https://www.cbos.pl/SPISKOM.POL/2021/K_001_21.PDF [dostęp: 14.03.2021].

Seligman, M. E. P. (2005). Prawdziwe szczęście. Poznań: Media Rodzina.

Thombs, B. D., Bonardi, O., Rice, D. B., Boruff, J. T., Azar, M., He, C., et al. (2020). Curating evidence on mental health during COVID-19: a living systematic review. Journal of Psychosomatic Research.133:110113. DOI: 10.1016/j.jpsychores.2020.110113.

UNICEF (2020). The impact of COVID-19 on the mental health of adolescents and youth. https://www.unicef.org/lac/en/impact-covid-19-mental-health-adolescents-and-youth [dostęp: 14.03.2021]. 